\title{
Circulating tumor DNA-based predictive biomarkers in breast cancer clinical trials: a narrative review
}

\author{
Oraianthi Fiste^, Michael Liontos^, Konstantinos Koutsoukos^, Evangelos Terpos^, \\ Meletios A. Dimopoulos^, Flora Zagouri^
}

Department of Clinical Therapeutics, School of Medicine, National and Kapodistrian University of Athens, Athens, Greece

Contributions: (I) Conception and design: O Fiste, F Zagouri; (II) Administrative support: All authors; (III) Provision of study materials or patients: O Fiste; (IV) Collection and assembly of data: O Fiste; (V) Data analysis and interpretation: O Fiste, F Zagouri; (VI) Manuscript writing: All authors; (VII) Final approval of manuscript: All authors.

Correspondence to: Oraianthi Fiste, MD, MSc. Department of Clinical Therapeutics, School of Medicine, National and Kapodistrian University of Athens, Alexandra Hospital 80 Vasilissis Sophias, 11528 Athens, Greece. Email: ofiste@med.uoa.gr.

\begin{abstract}
Breast carcinoma is the most frequent and the second leading cause of cancer mortality in women worldwide. Current treatment decisions are based on tumor profiling of the initial tissue biopsy. Cancer though evolves both spatially and temporarily in a significant percentage of patients during treatment. However, sequential biopsies from the primary tumor or its metastatic sites are not either convenient or feasible in the majority of cases. In the era of precision medicine, analysis of circulating bloodbased biomarkers in the field of liquid biopsies provides an insight into the dynamic molecular profiling of the primary tumor and its metastases, in a relatively non-invasive way. The latter permits not only patient stratification but also longitudinal evaluation of treatment response, when incorporated into clinical trials. This review summarizes the results from recent and ongoing circulating tumor DNA (ctDNA)based biomarker-driven clinical trials, with respect to ctDNA analysis' predictive role, both in adjuvant, neo-adjuvant, and metastatic setting. Furthermore, current challenges in ctDNA analysis applications are critically discussed, including pre-analytical and analytical issues, and future perspectives in this field, through the conduct of well-designed, multicenter, randomized, large-scale, biomarker-stratified trials, with robust statistical methods. Despite in its infancy, ctDNA analysis holds great promise as a minimally invasive tool regarding tailored, personalized treatment guidance for breast cancer patients.
\end{abstract}

Keywords: Breast cancer; circulating tumor DNA (ctDNA); clinical trials; predictive biomarkers

Submitted Feb 02, 2020. Accepted for publication Sep 06, 2020.

doi: 10.21037/atm-20-1175

View this article at: http://dx.doi.org/10.21037/atm-20-1175

\section{Introduction}

Breast cancer is the most prevalent cancer and the second leading cause of cancer mortality in women $(1,2)$. Nextgeneration sequencing (NGS)-based diagnostics have identified around 40 genomic alterations, shedding light into the heterogeneity of this disease $(3,4)$. Currently, only a few of these somatic alterations have been validated as therapeutic targets, whereas, there are multiple targeted therapies, effective as signalling blockade, in the adjuvant, neo-adjuvant, and metastatic settings.

In particular, trastuzumab (5-7), pertuzumab (8-10), adotrastuzumab emtansine (11), lapatinib (12) and neratinib (13)

$\wedge$ ORCID: Oraianthi Fiste: 0000-0002-7106-4162; Michael Liontos: 0000-0001-7192-4575; Konstantinos Koutsoukos: 0000-0002-1710-

125X; Evangelos Terpos: 0000-0001-5133-1422; Meletios Athanasios Dimopoulos: 0000-0001-8990-3254; Flora Zagouri: 0000-0001-71536556. 
are human epidermal growth factor receptor 2 (HER2) inhibitors for the treatment of HER2 + disease; palbociclb (14), ribociclib (15) and abemaciclib (16) are cyclin-dependent kinase 4 and $6(\mathrm{CDK} 4 / 6)$ inhibitors for the treatment of hormone-receptor (HR)+, HER2- disease, in combination with hormonal treatment, like aromatase inhibitors (AIs), tamoxifen or fulvestrant; everolimus (17) is a mammalian target of rapamycin (mTOR) inhibitor, also, for the treatment of HR+, HER2- disease, in combination with hormonal treatment; olaparib (18) and talazoparib (19) are poly adenosine diphosphate (ADP) ribose polymerase (PARP) inhibitors for the treatment of BReast CAncer gene (BRCA)+ disease; while alpelisib (20) is a phosphoinositide3 -kinase (PI3K) inhibitor for the treatment of phosphatidylinositol-4,5-bisphosphate 3-kinase, catalytic subunit alpha (PIK3CA)+ disease.

Despite the rapid advance in personalized medicine strategies, metastatic breast cancer remains an incurable disease, with a 5 -year survival rate of approximately $25 \%$ $(21,22)$. Breast cancer's plasticity, over time and under treatment pressure, represents the greatest challenge in its therapeutics, due to disease recurrence and drug resistance $(23,24)$. Thus, both American and European guidelines recommend reassessment of biomarkers, like HR and HER2 status, if feasible, in the metastatic setting (25).

Unfortunately, tissue biopsies are fraught with several caveats; they are invasive, patient-unfriendly procedures, not always feasible either because of patient's condition and comorbidities or because of tumor's accessibility, and they don't permit longitudinal monitoring of tumor (26-30). Thus, the ideal approach to address the diverse molecular profile of breast tumors would be a minimally invasive method that could capture the entire genetic make-up of the tumor, in 'real-time', during the course of treatment. Currently, analysis of circulating blood biomarkers, like circulating tumor DNA (ctDNA), under the umbrella-term of 'liquid biopsies', offers an attractive approach to evaluate patient's entire tumor burden, in a non-invasive, convenient, repetitive, dynamic, and cost-effective way (27,31-36).

Several studies have evaluated the emerging role of ctDNA in monitoring treatment response or resistance and in predicting early relapse (37-48). Nevertheless, studies investigating the potential capacity of serial ctDNA monitoring for treatment guidance are still scarce, smallscale, and lack a strict clinically-centered protocol. To the best of our knowledge, there is no other review focused on the incorporation of ctDNA-based predictive biomarkers in breast cancer patients enrolled in clinical trials, therefore, we performed this review of the published literature, to assess the potential of ctDNA in optimizing disease management.

We present the following article in accordance with the Narrative Review reporting checklist (available at http:// dx.doi.org/10.21037/atm-20-1175).

\section{Methods}

A review of published literature was conducted to assess the predictive value of ctDNA analysis in the setting of clinical trials in breast cancer patients. All eligible studies were identified by a search in www.clinicaltrials.gov, MEDLINE/ PubMed database and Cochrane Database of Systematic Reviews (CDSR) for the period up to August 31, 2019. Clinical Trials incorporating ctDNA analysis, as source of potential predictive biomarkers, in patients with breast cancer were considered for inclusion. To create a search strategy, medical subject heading $(\mathrm{MeSH})$ terms [breast, cancer, neoplasm, carcinoma, clinical trial, ctDNA, cell free DNA (cfDNA), predictive, biomarker] were used in addition with Boolean search terms (AND, OR).

Eligible for inclusion were considered all randomised and non-randomised clinical trials carried out in adult patients ( $\geq 18$ years old), irrespective of gender, with breast cancer, reporting results of ctDNA analysis and its correlation with treatment efficacy. Abstracts presented in conferences were also included.

Language restrictions were applied (only articles published in English were considered eligible). Animal studies, book chapters, observational study designs, commentaries, case reports, reviews, meta-analyses and studies not in cancer patients were also excluded.

The following data were extracted from each clinical trial: clinical trial name and Identification number (ID number), status, first author, year of publication, setting (primary or advanced breast cancer), line of therapy (neoadjuvant, adjuvant, and $1^{\text {st }}$ or $2^{\text {nd }}$ line for metastatic setting, etc.), pathological subtype/hormonal status, allocation of study (randomized, non-randomized), intervention model (sequential-, parallel-, single group-assignment), masking, phase, treatment modalities (intervention and control arm regimens), number of patients enrolled in biomarker sub-study, primary endpoint, ctDNA sequencing technique, results.

\section{Results}

Our search strategy retrieved initially 64 clinical trials, 
which were screened at title and abstract (if it was available) using the study inclusion criteria. In 43 ongoing clinical trials no data were mature, one was observational study, thus 20 clinical trials, containing data on 5,890 patients with evaluable ctDNA analyses, were finally eligible for this review. Characteristics of studies are presented in Table 1.

Preliminary results from Palbociclib and Circulating Tumor DNA for estrogen receptor-1 gene (ESR1) Mutation Detection (PADA-1) trial demonstrated that ESR1mut detection is uncommon in untreated AI-sensitive, ER+, HER2 - metastatic breast cancer patients (detection rate of $2.1 \%$ at baseline) and is related to prior $\mathrm{AI}$ exposure in the adjuvant setting $(4.9 \%$ with $\mathrm{AI}$ use $v s .0 \%$ without $\mathrm{AI}$ use, Yates Chi2: $\mathrm{P}=0.009)$. Remarkably, 1-month use of AI and palbociclib, the first CDK4/6 inhibitor approved as an anticancer regimen, led to undetectable ESR1mut in 13 among the 17 patients with ESR1mut detected at baseline (49).

In the PALOMA-3 study, which compared the combination of palbociclib plus fulvestrant to placebo plus fulvestrant, in patients with HR+, HER2- advanced breast cancer, progressing on prior endocrine therapy, changes in PIK3CA ctDNA dynamics upon 15 days treatment predicted response to targeted therapy in combination with fulvestrant (HR 3.94, 95\% CI, 1.61-9.64, log-rank $\mathrm{P}=0.0013$ ), while ESR1 ctDNA levels change was less predictive on progression free survival (PFS) on palbociclib plus fulvestrant $(14,43)$. Detection of PIK3CA and estrogen receptor-2 gene (ESR2) mutations in plasma ctDNA samples, compared with their detection in archived tissue samples, has been associated with significantly improved PFS and response to abemaciclib (another selective CDK4/6 inhibitor) plus fulvestrant, in postmenopausal women with HR+, HER2 - advanced breast cancer, progressing on prior endocrine therapy $(62,63)$.

On the contrary, ctDNA sequencing from 494 patients enrolled in the randomized MONALEESA-2 trial of letrozole \pm ribociclib, showed a consistent PFS benefit for the combination of endocrine therapy plus CDK4/6 inhibitor, regardless of the baseline status of ctDNA biomarkers [PIK3CA, tumor protein 53 (TP53), Zinc finger protein 703 (ZNF703)/fibroblast growth factor receptor 1 (FGFR1), ESR1] $(15,51)$. Consistent treatment benefit was observed for fulvestrant and ribociclib, irrespective of baseline ctDNA alteration status [PIK3CA, ESR1, TP53, CDC20 homolog 1 (CDH1), FGFR1/ZNF703/WolfHirschhorn syndrome candidate 1-like 1 (WHSC1L1)] in Phase III MONALEESA-3 study (52,53).

In BELLE-2, which evaluated the combination of the
panPI3 kinase inhibitor buparlisib with fulvestrant in patients with refractory to AI, HR+, HER2- advanced breast cancer, the presence of PIK3CA mutations in ctDNA corresponded to improved PFS in the buparlisib arm (7.0 vs. 3.2 months; $\mathrm{HR}=0.58$; $95 \% \mathrm{CI}, 0.41-0.82 ; 1$-sided nominal $\mathrm{P}=0.001)(54,55)$. Clinical benefit of the addition of buparlisib to fulvestrant in HR+, HER2- advanced breast cancer patients, with prior use of mTOR inhibitors, has also been observed in the randomized Phase III BELLE-3 trial, even if this benefit was irrespective of PIK3CA status in ctDNA (56). Both, BELLE-2 and BELLE-3 highlighted the potential of PIK3CA mutational status in plasma ctDNA as predictive biomarker for benefit of buparlisib treatment, in this subset of breast cancer patients; whereas the discordance in PIK3CA status between tumor tissue and ctDNA samples $(76.7 \%$ in BELLE- 2 vs. $84.8 \%$ in BELLE-3) underline the need for an optimal standardized assay.

In a single group assignment, Phase I/II trial the combination of alpelisib and nab-paclitaxel resulted in increased PFS in HER2- advanced breast cancer patients, harbouring ctDNA PIK3CA mutations (66).

A subsidiary analysis of the BOLERO-2 trial on 550 $\mathrm{ER}+$ advanced breast cancer patients, demonstrated that the addition of everolimus to exemestane prolonged PFS, irrespective of cfDNA PIK3CA mutation status ( $\mathrm{HR}=0.43$ and 0.37 respectively) $(17,69)$.

Furthermore, the ongoing POSEIDON trial and Neratinib HER Mutation Basket Study (SUMMIT) support the predictive value of early evaluation of ctDNA changes, before radiologic treatment response $(58,59)$.

The translational sub-study of the ongoing I-SPY 2 trial demonstrated the significance of serial monitoring of ctDNA in predicting response to neo-adjuvant treatment (61). ctDNA analysis of the NeoALTTO trial demonstrated that the detection of PIK3CA and/or TP53 mutations, in the baseline (before neo-adjuvant therapy) plasma sample was correlated with lower rates of pathological complete response, whereas persistent ctDNA detection both at baseline and after 14 days of neo-adjuvant therapy was significantly associated with the lowest rate of pathological complete response $(71,72)$.

In open-label WJOG6110B/ELTOP trial, whereas patients with HER2 + advanced breast cancer, were randomized to receive either lapatinib and capecitabine or trastuzumab and capecitabine, PIK3CA mutations in both tissue and ctDNA samples associated with shorter PFS, regardless of the treatment arm (57). The presence 
Table 1 Characteristics of clinical trials incorporating ctDNA-based predictive biomarkers

\begin{tabular}{|c|c|c|c|c|c|c|c|c|c|c|c|c|c|}
\hline $\begin{array}{l}\text { Clinical trial } \\
\text { (name/D } \\
\text { number) }\end{array}$ & Status & Design & $\begin{array}{l}\text { Intervention } \\
\text { model }\end{array}$ & Setting & Population characteristics & Intervention vs. Control arm & $\begin{array}{l}\text { Enrollment } \\
\text { (biomarker } \\
\text { analysis) }\end{array}$ & $\begin{array}{c}\text { Patients (\%) } \\
\text { with detectable } \\
\text { ctDNA }\end{array}$ & Endpoints & $\begin{array}{l}\text { ctDNA sequencing } \\
\text { technique }\end{array}$ & $\begin{array}{c}\text { Concordance } \\
\text { of tissue and } \\
\text { plasma samples }\end{array}$ & Results & References \\
\hline $\begin{array}{l}\text { PADA-1/ } \\
\text { NCT03079011 }\end{array}$ & $\begin{array}{l}\text { Active, not } \\
\text { recruiting }\end{array}$ & $\begin{array}{l}\text { Open label, } \\
\text { randomized, } \\
\text { phase III }\end{array}$ & $\begin{array}{l}\text { Sequential } \\
\text { assignment }\end{array}$ & $\begin{array}{l}\text { 1st line (metastatic } \\
\text { setting) }\end{array}$ & $\begin{array}{l}\text { ER+, HER2-, } \\
\text { postmenopausal female, } \\
\text { ECOG PS: 0-2 }\end{array}$ & $\begin{array}{l}\begin{array}{l}\text { Palbociclib + Al vs. palbociclib } \\
+ \text { fulvestrant }\end{array}\end{array}$ & 803 & 17/803 (2.1\%) & Safety, efficacy & ddPCR-based assay & & $\begin{array}{l}76.47 \% \text { of patients had undetectable ESR1m } \\
\text { after } 1 \text { month of palbociclib + Al therapy }\end{array}$ & (49) \\
\hline $\begin{array}{l}\text { SOLAR-1/ } \\
\text { NCT02437318 }\end{array}$ & $\begin{array}{l}\text { Active, not } \\
\text { recruiting }\end{array}$ & $\begin{array}{l}\text { Triple blind, } \\
\text { randomized } \\
\text { (1:1), phase III }\end{array}$ & $\begin{array}{l}\text { Parallel } \\
\text { assignment }\end{array}$ & $\begin{array}{l}\text { 2nd line (metastatic } \\
\text { setting) }\end{array}$ & $\begin{array}{l}\text { PIK3CAm, HR+, HER2-, } \\
\text { male or postmenopausal } \\
\text { female, } 1 \text { prior line of } \\
\text { endocrine therapy, ECOG } \\
\text { PS: 0-1 }\end{array}$ & $\begin{array}{l}\text { Alpelisib + fulvestrant vs. } \\
\text { placebo + fulvestrant }\end{array}$ & 549 & $\begin{array}{l}186 / 549 \\
(33.87 \%)\end{array}$ & PFS & $\begin{array}{l}\text { Assay developed by } \\
\text { Qiagen }\end{array}$ & $94.7 \%$ & $\begin{array}{l}\text { PFS of } 3.7 \text { months for tissue PIK3CAm and of } \\
10.9 \text { months for ctDNA PIK3CAAm. Treatment } \\
\text { benefit, with the combination of alpelisib and } \\
\text { fulvestrant, in PFS for patients with ctDNA } \\
\text { PIKCSCAm, irespective of prior treatment for } \\
\text { advanced breast cancer and/or prior CDK } 4 / 6 \\
\text { inhibitors use }\end{array}$ & $(20,50)$ \\
\hline $\begin{array}{l}\text { MONALEESA-2/ } \\
\text { NCT01958021 }\end{array}$ & $\begin{array}{l}\text { Active, not } \\
\text { recruiting }\end{array}$ & $\begin{array}{l}\text { Double blind, } \\
\text { randomized } \\
\text { (1:1), phase III }\end{array}$ & $\begin{array}{l}\text { Parallel } \\
\text { assignment }\end{array}$ & $\begin{array}{l}\text { 1st line (metastatic } \\
\text { setting) }\end{array}$ & $\begin{array}{l}\text { HR+, HER2-, } \\
\text { postmenopausal female, } \\
\text { ECOG PS: 0-1 }\end{array}$ & $\begin{array}{l}\text { Ribociclib + letrozole vs. } \\
\text { placebo + letrozole }\end{array}$ & 494 & $427 / 494(86 \%)$ & PFS & NGS & & $\begin{array}{l}21 \text { ctDNA genomic alteration: PIK3CA (33\%), } \\
\text { TP53 (12\%), ZNFF } 03 / \text { FFFRR1 (5\%), ESR1 }(4 \%) \text {, } \\
\text { and in genes involved in RTK signaling (12\%). } \\
\text { Treatment benefit, with the combination of } \\
\text { ribociclib and letrozole, irrespective of ctDNA } \\
\text { genetic alterations at baseline }\end{array}$ & $(15,51)$ \\
\hline $\begin{array}{l}\text { MONALEESA-3/ } \\
\text { NCT02422615 }\end{array}$ & $\begin{array}{l}\text { Active, not } \\
\text { recruiting }\end{array}$ & $\begin{array}{l}\text { Double blind, } \\
\text { randomized } \\
\text { (2:1), phase III }\end{array}$ & $\begin{array}{l}\text { Parallel } \\
\text { assignment }\end{array}$ & $\begin{array}{l}\leq 2 \text { nd line (metastatic } \\
\text { setting) }\end{array}$ & $\begin{array}{l}\text { HR+, HER2-, } \\
\text { postmenopausal female, } \\
\leq 1 \text { prior line of endocrine } \\
\text { therapy ECOG PS: } 0-1\end{array}$ & $\begin{array}{l}\text { Ribociclib + fulvestrant vs. } \\
\text { placebo + fulvestrant }\end{array}$ & 600 & $\begin{array}{l}124 / 600 \\
(20.66 \%) \text { for } \\
\text { PIK3CAm }\end{array}$ & PFS & NGS & & 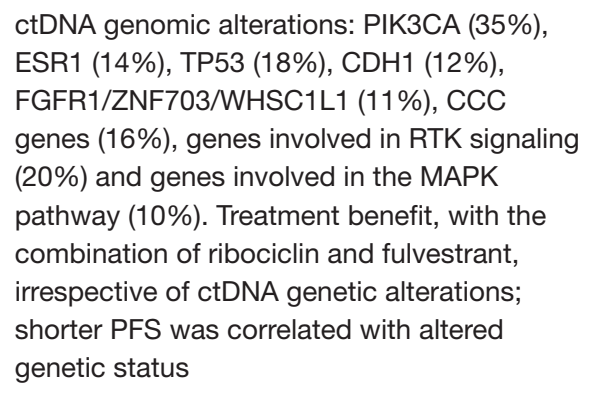 & $(52,53)$ \\
\hline $\begin{array}{l}\text { BELLE-2/ } \\
\text { NCT01610284 }\end{array}$ & Completed & $\begin{array}{l}\text { Double blind, } \\
\text { randomized } \\
\text { (1:1), phase III }\end{array}$ & $\begin{array}{l}\text { Parallel } \\
\text { assignment }\end{array}$ & $\begin{array}{l}\text { 2nd line (metastatic } \\
\text { setting) }\end{array}$ & $\begin{array}{l}\text { HR+, HER2-, } \\
\text { postmenopausal female, } \\
\text { Al-refractory disease }\end{array}$ & $\begin{array}{l}\text { Buparlisib + fulvestrant vs. } \\
\text { placebo + fulvestrant }\end{array}$ & 587 & $200 / 587(34 \%)$ & PFS & Sanger sequencing & $77 \%$ & $\begin{array}{l}64 \text { of } 307(21 \%) \text { patients with PIK3CAwt } \\
\text { tumour tissue had PIK3CAm ctDNA, indicating } \\
\text { evolution between initial diagnosis and the } \\
\text { present time. ctDNA PIK3CAm corresponded } \\
\text { to improved median PFS in the buparlisib } \\
\text { arm }(7.0 \text { vs. } 3.2 \text { months; ; RR }=0.58 ; \text {; } 5 \% \text { Cl, } \\
0.41-0.82 ; 1 \text {-sided nominal P=0.001) }\end{array}$ & $(54,55)$ \\
\hline $\begin{array}{l}\text { BELLE-3/ } \\
\text { NCT01633060 }\end{array}$ & Terminated & $\begin{array}{l}\text { Double blind, } \\
\text { randomized } \\
\text { (2:1), phase III }\end{array}$ & $\begin{array}{l}\text { Parallel } \\
\text { assignment }\end{array}$ & $\begin{array}{l}\geq 2 \text { nd line (metastatic } \\
\text { setting) }\end{array}$ & $\begin{array}{l}\text { HR+, HER2-, } \\
\text { postmenopausal female, } \\
\text { prior treatment with } \\
\text { Al, progression to the } \\
\text { combination of mTORi and } \\
\text { endocrine therapy, ECOG } \\
\text { PS: 0-2 }\end{array}$ & $\begin{array}{l}\text { Buparlisib + fulvestrant vs. } \\
\text { placebo + fulvestrant }\end{array}$ & 348 & 135/348 (39\%) & PFS & $\begin{array}{l}\text { Inostics BEAMing } \\
\text { assay }\end{array}$ & $83 \%$ & $\begin{array}{l}\text { Treatment benefit, with the combination } \\
\text { of buparlisib and fulvestrant, irrespective } \\
\text { of ctDNA PIK3CACA mutatitional status (PFS } \\
\text { of } 4.2 \text { vs. } 1.6 \text { months; } \mathrm{HR}=0.46 ; 95 \% \mathrm{Cl} \\
0.29-0.73 ; \mathrm{P}=0.00031 \text { for PIK3CAm and } 3.9 \\
\text { vs. } 2.7 \text { months; } \mathrm{HR}=0.73 ; 95 \% \mathrm{Cl}, 0.53-1.00 \text {; } \\
\mathrm{P}=0.026 \text { for PIK3CAwt) }\end{array}$ & (56) \\
\hline
\end{tabular}

Table 1 (continued) 


\begin{tabular}{|c|c|c|c|c|c|c|c|c|c|c|c|c|c|}
\hline $\begin{array}{l}\text { Clinical trial } \\
\text { (name/ID } \\
\text { number) }\end{array}$ & Status & Design & $\begin{array}{l}\text { Intervention } \\
\text { model }\end{array}$ & Setting & Population characteristics & Intervention vs. Control arm & $\begin{array}{l}\text { Enrollment } \\
\text { (biomarker } \\
\text { analysis) }\end{array}$ & $\begin{array}{l}\text { Patients (\%) } \\
\text { with detectable } \\
\text { ctDNA }\end{array}$ & Endpoints & $\begin{array}{l}\text { ctDNA sequencing } \\
\text { technique }\end{array}$ & $\begin{array}{l}\text { Concordance } \\
\text { of tissue and } \\
\text { plasma samples }\end{array}$ & Results & References \\
\hline $\begin{array}{l}\text { PALOMA-3/ } \\
\text { NCT01942135 }\end{array}$ & $\begin{array}{l}\text { Active, not } \\
\text { recruiting }\end{array}$ & $\begin{array}{l}\text { Double blind, } \\
\text { randomized } \\
\text { (2:1), phase III }\end{array}$ & $\begin{array}{l}\text { Parallel } \\
\text { assignment }\end{array}$ & $\begin{array}{l}\text { 2nd line (metastatic } \\
\text { setting) }\end{array}$ & $\begin{array}{l}\text { HR+, HER2-, female of } \\
\text { any menopausal status, } \\
\text { progression to prior } \\
\text { adjuvant or metastatic } \\
\text { endocrine therapy, ECOG } \\
\text { PS: } 0-1\end{array}$ & $\begin{array}{l}\text { Palbociclib + fulvestrant vs. } \\
\text { placebo + fulvestrant }\end{array}$ & 455 & $\begin{array}{l}\text { 100/455 (22\%) } \\
\text { for PIK3CAm } \\
\text { and } 114 / 445 \\
(25.6 \%) \text { for } \\
\text { ESR1m }\end{array}$ & PFS & ddPCR-based assay & & $\begin{array}{l}\text { Both PIK3CA mutant copies and wild-type } \\
\text { allele and ESR1 mutant copies and wild- } \\
\text { type alldele were significantly lower in the } \\
\text { Palbociclib treatment group (Wilcoxon signed- } \\
\text { rank test, } P<0.0001) \text {. Early ctDNA PIK3CA } \\
\text { dynamics (after } 2 \text { weeks of therapy) were } \\
\text { predictcive on response to palbociclib and } \\
\text { fulvestrant }\end{array}$ & $(14,43)$ \\
\hline $\begin{array}{l}\text { WJOG6110B/ } \\
\text { ELTOP/ } \\
\text { UMIN000005219 }\end{array}$ & Completed & $\begin{array}{l}\text { Open label, } \\
\text { randomized } \\
(1: 1) \text {, phase II }\end{array}$ & $\begin{array}{l}\text { Parallel } \\
\text { assignment }\end{array}$ & $\begin{array}{l}\geq 1 \text { st line (metastatic } \\
\text { setting) }\end{array}$ & $\begin{array}{l}\text { HER2+, female, prior use } \\
\text { of taxanes, progression on } \\
\text { trastuzumab-containing } \\
\text { regimens, ECOG PS: 0-2 }\end{array}$ & $\begin{array}{l}\text { Lapatinib + capecitabine vs. } \\
\text { trastuzumab + capecitabine }\end{array}$ & 35 & $8 / 35(23 \%)$ & PFS & ddPCR-based assay & $85 \%$ & $\begin{array}{l}\text { PIK3CAm in both tissue and plasma samples } \\
\text { correlated with shorter PFS, irrespective } \\
\text { of the treatment arm. Especially, for ctDNA } \\
\text { PIK3CAwt PFS was } 8.2 \text { and } \\
4.9 \text { months for the lapatinib arm and for the } \\
\text { trastuzumab arm, respectively (HR =0.38; } \\
95 \% \text { Cl, } 0.16-0.93 ; \mathrm{P}=0.035 \text { ), whereas for } \\
\text { ctDNA PIK3CAm PFS was } 4.1 \text { and } \\
6.1 \text { months for the lapatinib arm and for the } \\
\text { trastuzumab arm, respectively (HR =0.60; } \\
95 \% \mathrm{Cl}, 0.11-3.13 ; \mathrm{P}=0.54 \text { ) }\end{array}$ & (57) \\
\hline $\begin{array}{l}\text { POSEIDON/ } \\
\text { NCT02285179 }\end{array}$ & Recruiting & $\begin{array}{l}\text { Double blind, } \\
\text { randomized } \\
\text { (1:1), phase lb } \\
\text { ( } 3+3 \text { design })\end{array}$ & $\begin{array}{l}\text { Parallel } \\
\text { assignment }\end{array}$ & $\begin{array}{l}\geq 2 \text { nd line (metastatic } \\
\text { setting) }\end{array}$ & $\begin{array}{l}\text { HR+, HER2-, female of } \\
\text { any menopausal status, } \\
\text { prior endocrine therapy, } \leq 5 \\
\text { chemotherapy lines in the } \\
\text { metastatic setting }\end{array}$ & $\begin{array}{l}\text { Taselisib + tamoxifen vs. } \\
\text { placebo + tamoxifen }\end{array}$ & 22 & & PFS & $\begin{array}{l}\text { dPCR/tagged amplicon } \\
\text { deep-sequencing }\end{array}$ & & $\begin{array}{l}\text { ctDNA PIK3CA dynamics were predictive on } \\
\text { response to taselisib and tamoxifen, before } \\
\text { radiologic treatment response }\end{array}$ & (58) \\
\hline $\begin{array}{l}\text { SUMMIT/ } \\
\text { NCT03433274 }\end{array}$ & Recruiting & $\begin{array}{l}\text { Open } \\
\text { label, non- } \\
\text { randomized, } \\
\text { phase II }\end{array}$ & $\begin{array}{l}\text { Single group } \\
\text { assignment }\end{array}$ & $\begin{array}{l}\text { BASKET trial: colon, } \\
\text { lung, breast, bladder } \\
\text { cancer, fibromellar } \\
\text { carcinoma, any line of } \\
\text { therapy }\end{array}$ & $\begin{array}{l}\text { HER2+ or EGFR+ or } \\
\text { HER3+ }\end{array}$ & Neratinib & 14 & $11 / 14(78.57 \%)$ & Clinical benefit rate & $\begin{array}{l}\text { 70-gene digital } \\
\text { sequencing assay }\end{array}$ & $93.5 \%$ & $\begin{array}{l}\text { Early ctDNA HER2 dynamics were predictive } \\
\text { on response to neratinibib ctDNA HER2mut } \\
\text { frequency decreased in } 9 \text { of } 11 \text { paired } \\
\text { samples, at week } 4 \text {, followed by an increase } \\
\text { upon radiographical disease progression at } \\
\text { week } 8\end{array}$ & (59) \\
\hline $\begin{array}{l}\text { BEECH/ } \\
\text { NCT01625286 }\end{array}$ & $\begin{array}{l}\text { Active, not } \\
\text { recruiting }\end{array}$ & $\begin{array}{l}\text { Double blind, } \\
\text { randomized } \\
(1: 1) \text {, phase } \\
\text { 1/II }\end{array}$ & $\begin{array}{l}\text { Parallel } \\
\text { assignment }\end{array}$ & $\begin{array}{l}\text { 1st line (metastatic } \\
\text { setting) }\end{array}$ & $\begin{array}{l}\text { ER+, HER2-, WHO PS: } \\
0-1\end{array}$ & $\begin{array}{l}\text { Capivasertib + paclitaxel vs. } \\
\text { placebo + paclitaxel }\end{array}$ & 148 & & $\begin{array}{l}\text { Dose-limiting } \\
\text { toxicity events, PFS }\end{array}$ & $\begin{array}{l}\text { ddPCR-based assay for } \\
\text { ctDNA quantification. } \\
\text { Roche cobas PIK3CA } \\
\text { assay for PIK3CAmut } \\
\text { identification }\end{array}$ & & $\begin{array}{l}\text { Early ctDNA dynamics were predictive on PFS } \\
\text { irrespective of treatment arm (median PFS } \\
\text { was } 11.1 \text { months in patients with decreased } \\
\text { ctDNA levels at week } 4 \text {, and } 6.4 \text { months in } \\
\text { patients with higher ctDNA levels; } H R=0.20 \text {; } \\
95 \% \text { Cl, } 0.083-0.50 ; P<0.0001 \text { ) }\end{array}$ & (60) \\
\hline $\begin{array}{l}\text { I-SPY 2/ } \\
\text { NCT01042379 }\end{array}$ & Recruiting & $\begin{array}{l}\text { Open label, } \\
\text { randomized, } \\
\text { phase II } \\
\text { (adaptive } \\
\text { design) }\end{array}$ & $\begin{array}{l}\text { Parallel } \\
\text { assignment }\end{array}$ & $\begin{array}{l}\text { Locally advanced } \\
\text { breast cancer (stage II, } \\
\text { III), neoadjuvant setting }\end{array}$ & $\begin{array}{l}\text { Any tumor ER/PR/HER2 } \\
\text { status, female, no prior } \\
\text { cytotoxic regimens, ECOG } \\
\text { PS: 0-1 }\end{array}$ & 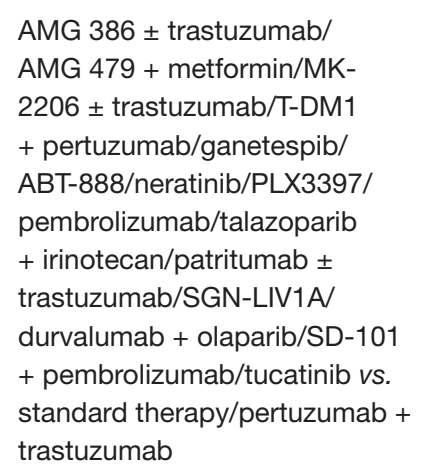 & 84 & & $\begin{array}{l}\mathrm{PCR} \text { after the use of } \\
\text { experimental agents }\end{array}$ & $\begin{array}{l}\text { Mutational profiles } \\
\text { derived from } \\
\text { pretreatment tumor } \\
\text { biopsy and germline } \\
\text { DNA whole exome } \\
\text { sequencing were used } \\
\text { to design personalized } \\
\text { assays }\end{array}$ & & $\begin{array}{l}\text { Early ctDNA dynamics were predictive on } \\
\text { response to neoadjuvant treatment }\end{array}$ & (61) \\
\hline
\end{tabular}

trastuzumab 


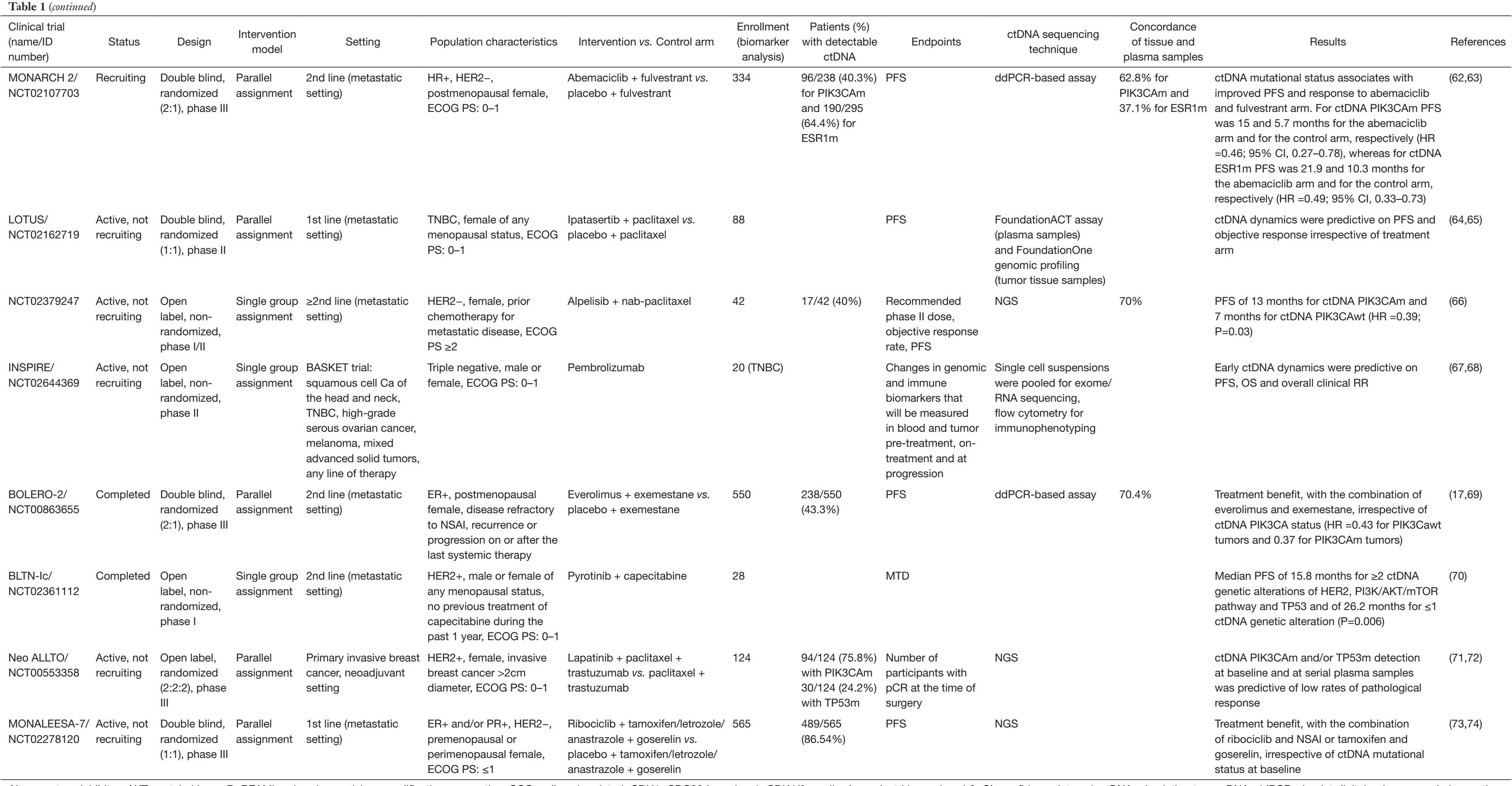

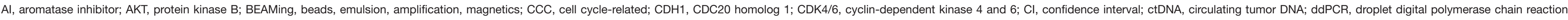

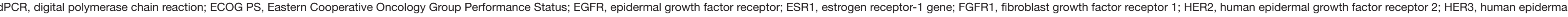

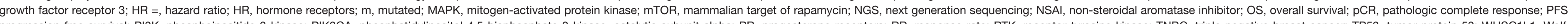

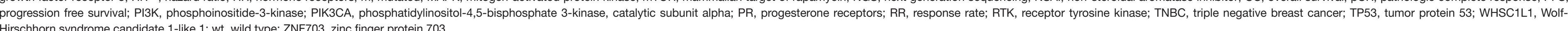


of concomitant genetic alterations of HER2, PI3K/ protein kinase B (AKT)/mTOR pathway and TP53 in ctDNA analysis was significantly correlated with worse PFS, compared to $\leq 1$ genetic alteration, in the open-label, Phase I BLTN-Ic trial, of the combination of pyrotinib plus capecitabine in HER2+ advanced breast cancer patients (70).

Dynamic ctDNA analysis of plasma samples from Phase I/II trial BEECH, whereas patients with ER+ metastatic breast cancer randomized to either paclitaxel plus AKT inhibitor capivasertib or paclitaxel plus placebo, predicted long-term outcome (PFS of 11.1 months in patients with suppressed ctDNA at 21 days vs. 6.4 months in patients with high levels of ctDNA, HR $=0.20 ; 95 \%$ CI, 0.083-0.50; $\mathrm{P}<0.0001)$, thus serving as a surrogate for PFS (60).

The double-blind, Phase II LOTUS trial, comparing the combination of ipatasertib plus paclitaxel with paclitaxel monotherapy in triple negative advanced breast cancer patients, demonstrated the predictive value of dynamic evaluation of ctDNA in evaluating both objective response and PFS, consistently in both arms $(64,65)$.

As part of the Phase II, INSPIRE basket trial, a secondary analysis of ctDNA at baseline and before the initiation of 3 rd cycle of the single-agent immune checkpoint inhibitor pembrolizumab in 10 triple negative metastatic breast cancer patients, strongly correlated with PFS, overall survival (OS) and overall clinical response rate (ORR) $(67,68)$.

In the 1st comprehensive genomic analysis of ctDNA of premenopausal patients with ER+ and/or progesterone receptors $(\mathrm{PR})+$, HER 2 - advanced breast cancer, the combination of the CDK 4/6 inhibitor ribociclib and non-steroidal aromatase inhibitor (NSAI) or tamoxifen and goserelin resulted in PFS benefit, irrespective of the baseline genetic landscape status $(73,74)$.

Based on the results of SOLAR-1, Food and Drug Administration (FDA) approved, on May 24, 2019, the use of PIK3CA selective inhibitor alpelisib in combination with fulvestrant for the treatment of men and postmenopausal women, with HR+, HER2-, PIK3CA-mutated advanced breast cancer, following disease progression on or after an endocrine-based regimen. In particular, the combination of alpelisib and fulvestrant resulted in significant prolongation of PFS (HR 0.55; 95\% CI, 0.39-0.79; $\mathrm{n}=186$ ) in patients with ctDNA PIK3CA mutant status. Concurrently, FDA also approved the companion diagnostic test PIK3CA Rotor-Gene Q real-time polymerase chain reaction (RGQ PCR) kit to detect the PIK3CA mutation in a tissue and/or a liquid biopsy. Thus, the assessment of PIK3CA mutations in ctDNA became the first liquid biopsy to be used in the clinical setting for breast cancer patients $(20,50)$.

\section{Discussion}

Research into understanding breast cancer's complexity, both at cellular and molecular level, and development of targeted therapies underline the urgent need of conducting novel biomarker-driven clinical trials, with the ultimate goal of optimizing disease management. The traditional process of drug research and development, where investigational drugs were evaluated for safety and optimal dosing scheme in Phase I, for early signs of efficacy in Phase II, and for confirmation of efficacy, effectiveness and safety in Phase III, gradually fades out. Over the last decade, novel clinical trial designs have found their way into clinical research, in order not only to streamline but also to expedite drug development (75).

Master Protocol (MAPs) use a single, biomarkerdriven, trial design and protocol to concurrently evaluate multiple drugs and/or diseases, and include (I) basket trials, which enrol patients based on the presence of a specific biomarker (e.g., mutation), regardless of histology, to identify efficacy of a biomarker-specific, thus targeted, therapy, and (II) umbrella and (III) adaptive platform trials, where patients who share the same cancer histology are allocated to different arms, based on their biomarker status (e.g., mutation), in order to evaluate new investigational agents matches to biomarker-derived cohorts (75). The main difference between umbrella and platform trials is that the last incorporate more adaptions, during the trial, based on efficacy results of interim analyses, by permitting in a flexible way the addition or exclusion of new treatment modalities (75).

Establishing biomarker-stratified clinical-trial design frameworks in the context of spatial and temporal heterogeneity is challenging because the traditional use of archival tissue samples may not be reflective of the dynamic genomic status of the tumor, especially in the metastatic setting $(26,30)$. Such hurdle could potentially be overcome through the incorporation of ctDNA analyses, for the longitudinal evaluation of predictive biomarkers. Overall, results emerged from the clinical trials presented in this review highlight the importance of dynamic ctDNA monitoring in the era of precision medicine; measurement of ctDNA provides representative data of spatiotemporal tracking of mutational landscape of both primary tumour and metastases, thus serving as a sensitive biomarker 
for both monitoring tumor progression and evaluating treatment response $(37,76)$.

ctDNA dynamics could serve as a predictive biomarker independent of the histology. Indeed, the I-SPY 2 trial reported that early ctDNA dynamics could predict response to neo-adjuvant treatment (61), whereas in the basket trial SUMMIT a decrease in ctDNA HER2 mutation variant allele frequency during treatment with the panHER inhibitor neratinib was followed by an increase upon radiographically proven progression (59).

Moreover, in the SUMMIT trial a number of genetic aberrations were also identified co-occurring with HER2 mutations, which highlighted the acquisition of secondary resistance to targeted therapy due to clonal evolution (59). Also, in the PALOMA-3 trial, which enrolled patients with ER+, HER2- advanced, previously progressed on endocrine treatment, breast cancer, early ctDNA dynamics of truncal mutations in PIK3CA predicted sensitivity to the CDK4/6 inhibitor palbociclib; on the contrary, serial ctDNA monitoring of the, commonly sub clonal, ESR1 mutations failed to predict clinical outcome (43). Taken together, these results address the importance of assessing tumor's genetic heterogeneity and clonal evolution in real time, with minimally invasive ways, like ctDNA analyses, in order not only to predict response, but also to rapidly identify acquired resistance to targeted therapies in breast cancer.

Regarding breast cancer detection, at present mammography remains the gold standard screening method, whereas gene expression profiling tests are used to stratify patients regarding recurrence (77). The potential of ctDNA analysis both as a consistent detection biomarker and as an accurate predictor of breast cancer recurrence risk needs to be further investigated, given the data scarcity and the lack of standardized analytical methods.

Nowadays, digital PCR (dPCR)- and next generation sequencing (NGS)-based methods are most frequently used to detect ctDNA in a background of wildtype DNA. Despite the wide variety in the number of available technologies for ctDNA analysis, only 2 companion diagnostic kits are FDAapproved: cobas EGFR Mutations Test v2 for detection of epidermal growth factor receptor (EGFR) mutations in nonsmall cell lung cancer (NSCLC), and therascreen ${ }^{\circledR}$ PIK3CA RGQ PCR Kit for detection of PIK3CA mutations in advanced or metastatic breast cancer (78).

Standardization challenges for integration of ctDNA analysis into routine clinical practice include: (I) biological variability (thus tumor heterogeneity), (II) pre-analytical variability (e.g., specialized collecting tubes to prevent leukocyte lysis, optimal time period between blooddraw and sample processing, centrifugation conditions, quantification methods), and (III) analytical variability (an ideal technology should be accurate, highly sensitive and specific, robust, and cost-effective) (76). To accelerate the development and establishment of liquid biopsies in clinical practice, consortium of researchers from academia, industry, regulatory agencies and public, both in United States (BloodPAC) (79), and Europe (Cancer-ID) (80) have been developed.

\section{Conclusions}

In conclusion, it can be said that the majority of published results from both recent and ongoing biomarker-driven clinical trials in breast cancer patients seem to concur that ctDNA profiling may significantly correlate with response to targeted therapies, thus indicating its potential as a non-invasive predictive biomarker, both in adjuvant, neoadjuvant, and metastatic setting.

The incorporation of ctDNA analysis into sophisticated, biomarker-driven clinical trials, with adequate statistical power and sufficient sample sizes, remains the most reliable way to demonstrate not only the analytical and clinical validity, but also the clinical utility of ctDNA as liquid biopsy, in tailoring decision-making in breast cancer patients.

\section{Acknowledgments}

Funding: None.

\section{Footnote}

Reporting Checklist: The authors have completed the Narrative Review reporting checklist. Available at http:// dx.doi.org/10.21037/atm-20-1175

Conflicts of Interest: All authors have completed the ICMJE uniform disclosure form (available at http://dx.doi. org/10.21037/atm-20-1175). ML reports personal fees from Roche, Astra Zeneca, Astellas, MSD, Ipsen, Jansen, BMS, GSK, outside the submitted work; Spouse is Pfizer employee. KK reports personal fees from Roche, BMS, MSD, IPSEN, outside the submitted work. ET reports grants, personal fees and non-financial support from JANSSEN, personal fees from CELGENE, grants, personal fees and non-financial support from TAKEDA, grants, 
personal fees and non-financial support from AMGEN, grants, personal fees and non-financial support from GENESIS PHARMA, personal fees from BMS, outside the submitted work. MAD reports personal fees from Janssen, Celgene, Takeda, Amgen, Genesis Pharma, BMS, outside the submitted work. FZ reports personal fees from Astra Zeneca, Daiichi, Eli-Lilly, Merck, Novartis, Pfizer, Roche, outside the submitted work. OF has no conflicts of interest to declare.

Ethical Statement: The authors are accountable for all aspects of the work in ensuring that questions related to the accuracy or integrity of any part of the work are appropriately investigated and resolved.

Open Access Statement: This is an Open Access article distributed in accordance with the Creative Commons Attribution-NonCommercial-NoDerivs 4.0 International License (CC BY-NC-ND 4.0), which permits the noncommercial replication and distribution of the article with the strict proviso that no changes or edits are made and the original work is properly cited (including links to both the formal publication through the relevant DOI and the license). See: https://creativecommons.org/licenses/by-nc-nd/4.0/.

\section{References}

1. Ferlay J, Soerjomataram I, Dikshit R, et al. Cancer incidence and mortality worldwide: sources, methods and major patterns in GLOBOCAN 2012. Int J Cancer 2015;136:E359-E386.

2. Bertucci F, Houlgatte R, Benziane A, et al. Gene expression profiling of primary breast carcinomas using arrays of candidate genes. Hum Mol Genet 2000;9:2981-91.

3. Stephens PJ, Tarpey PS, Davies H, et al. The landscape of cancer genes and mutational processes in breast cancer. Nature 2012;486:400-4.

4. Cancer Genome Atlas Network. Comprehensive molecular portraits of human breast tumours. Nature 2012;490:61-70.

5. Cameron D, Piccart-Gebhart MJ, Gelber RD, et al. 11 years' follow-up of trastuzumab after adjuvant chemotherapy in HER2-positive early breast cancer: final analysis of the HERceptin Adjuvant (HERA) trial. Lancet 2017;389:1195-205.

6. Gianni L, Eiermann W, Semiglazov V, et al. Neoadjuvant and adjuvant trastuzumab in patients with HER2-positive locally advanced breast cancer (NOAH): follow-up of a randomised controlled superiority trial with a parallel
HER2-negative cohort. Lancet Oncol 2014;15:640-7.

7. Slamon DJ, Leyland-Jones B, Shak S, et al. Use of chemotherapy plus a monoclonal antibody against HER2 for metastatic breast cancer that overexpresses HER2. N Engl J Med 2001;344:783-92.

8. von Minckwitz G, Procter M, de Azambuja E, et al. Adjuvant Pertuzumab and Trastuzumab in Early HER2Positive Breast Cancer. N Engl J Med 2017;377:122-31.

9. Gianni L, Pienkowski T, Im YH, et al. 5-year analysis of neoadjuvant pertuzumab and trastuzumab in patients with locally advanced, inflammatory, or early-stage HER2-positive breast cancer (NeoSphere): a multicentre, open-label, phase 2 randomised trial. Lancet Oncol 2016;17:791-800.

10. Swain SM, Kim SB, Cortés J, et al. Pertuzumab, trastuzumab, and docetaxel for HER2-positive metastatic breast cancer (CLEOPATRA study): overall survival results from a randomised, double-blind, placebo-controlled, phase 3 study. Lancet Oncol 2013;14:461-71.

11. Krop IE, Kim SB, Martin AG, et al. Trastuzumab emtansine versus treatment of physician's choice in patients with previously treated HER2-positive metastatic breast cancer (TH3RESA): final overall survival results from a randomised open-label phase 3 trial. Lancet Oncol 2017;18:743-54.

12. Geyer CE, Forster J, Lindquist D, et al. Lapatinib plus capecitabine for HER2-positive advanced breast cancer. $\mathrm{N}$ Engl J Med 2006;355:2733-43.

13. Martin M, Holmes FA, Ejlertsen B, et al. Neratinib after trastuzumab-based adjuvant therapy in HER2-positive breast cancer (ExteNET): 5-year analysis of a randomised, double-blind, placebo-controlled, phase 3 trial. Lancet Oncol 2017;18:1688-700.

14. Cristofanilli M, Turner NC, Bondarenko I, et al. Fulvestrant plus palbociclib versus fulvestrant plus placebo for treatment of hormone-receptor-positive, HER2negative metastatic breast cancer that progressed on previous endocrine therapy (PALOMA-3): final analysis of the multicentre, double-blind, phase 3 randomised controlled trial. Lancet Oncol 2016;17:425-39.

15. Hortobagyi GN, Stemmer SM, Burris HA, et al. Ribociclib as First-Line Therapy for HR-Positive, Advanced Breast Cancer. N Engl J Med 2016;375:1738-48.

16. Goetz MP, Toi M, Campone M, et al. MONARCH 3: Abemaciclib As Initial Therapy for Advanced Breast Cancer. J Clin Oncol 2017;35:3638-46.

17. Baselga J, Campone M, Piccart M, et al. Everolimus in postmenopausal hormone-receptor-positive advanced 
breast cancer. N Engl J Med 2012;366:520-9.

18. Robson M, Im SA, Senkus E, et al. Olaparib for Metastatic Breast Cancer in Patients with a Germline BRCA Mutation. N Engl J Med 2017;377:523-33.

19. Litton JK, Rugo HS, Ettl J, et al. Talazoparib in Patients with Advanced Breast Cancer and a Germline BRCA Mutation. N Engl J Med 2018;379:753-63.

20. André F, Ciruelos E, Rubovszky G, et al. Alpelisib for PIK3CA-Mutated, Hormone Receptor-Positive Advanced Breast Cancer. N Engl J Med 2019;380:1929-40.

21. Cardoso F, Spence D, Mertz S, et al. Global analysis of advanced/metastatic breast cancer: Decade report (20052015). Breast 2018;39:131-8.

22. Howlader N, Noone AM, Krapcho M, et al. editors. SEER Cancer Statistics Review, 1975-2016, National Cancer Institute. Bethesda, MD, based on November 2018 SEER data submission, posted to the SEER web site, April 2019.

23. Wang R, Li X, Zhang H, et al. Cell-free circulating tumor DNA analysis for breast cancer and its clinical utilization as a biomarker. Oncotarget 2017;8:75742-55.

24. National Comprehensive Cancer Network, Inc. 2018. Available online: https://www.nccn.org/

25. Cardoso F, Harbeck N, Fallowfield L, et al. Locally recurrent or metastatic breast cancer: ESMO Clinical Practice Guidelines for diagnosis, treatment and followup. Ann Oncol 2012;23:vii11-vii19.

26. Gerlinger M, Rowan AJ, Horswell S, et al. Intratumor heterogeneity and branched evolution revealed by multiregion sequencing. N Engl J Med 2012;366:883-92.

27. Yates LR, Gerstung M, Knappskog S, et al. Subclonal diversification of primary breast cancer revealed by multiregion sequencing. Nat Med 2015;21:751-9.

28. Nik-Zainal S, Van Loo P, Wedge DC, et al. The life history of 21 breast cancers. Cell 2012;149:994-1007.

29. Gundem G, Van Loo P, Kremeyer B, et al. The evolutionary history of lethal metastatic prostate cancer. Nature 2015;520:353-7.

30. Lipinski KA, Barber LJ, Davies MN, et al. Cancer Evolution and the Limits of Predictability in Precision Cancer Medicine. Trends Cancer 2016;2:49-63.

31. Ziegler A, Zangemeister-Wittke U, Stahel RA. Circulating DNA: a new diagnostic gold mine? Cancer Treat Rev 2002;28:255-71.

32. Han SX, Zhou X, Sui X, et al. Serum dickkopf-1 is a novel serological biomarker for the diagnosis and prognosis of pancreatic cancer. Oncotarget 2015;6:19907-17.

33. Kosaka N, Iguchi H, Ochiya T. Circulating microRNA in body fluid: a new potential biomarker for cancer diagnosis and prognosis. Cancer Sci 2010;101:2087-92.

34. Shah SP, Morin RD, Khattra J, et al. Mutational evolution in a lobular breast tumour profiled at single nucleotide resolution. Nature 2009;461:809-13.

35. Ellsworth RE, Blackburn HL, Shriver CD, et al. Molecular heterogeneity in breast cancer: State of the science and implications for patient care. Semin Cell Dev Biol 2017;64:65-72.

36. Zardavas D, Irrthum A, Swanton C, et al. Clinical management of breast cancer heterogeneity. Nat Rev Clin Oncol 2015;12:381-94.

37. Dawson SJ, Tsui DW, Murtaza M, et al. Analysis of circulating tumor DNA to monitor metastatic breast cancer. N Engl J Med 2013;368:1199-209.

38. Schiavon G, Hrebien S, Garcia-Murillas I, et al. Analysis of ESR1 mutation in circulating tumor DNA demonstrates evolution during therapy for metastatic breast cancer. Sci Transl Med 2015;7:313ra182.

39. Fribbens C, Garcia Murillas I, Beaney M, et al. Tracking evolution of aromatase inhibitor resistance with circulating tumour DNA analysis in metastatic breast cancer. Ann Oncol 2018;29:145-53.

40. Wang P, Bahreini A, Gyanchandani R, et al. Sensitive Detection of Mono- and Polyclonal ESR1 Mutations in Primary Tumors, Metastatic Lesions, and Cell-Free DNA of Breast Cancer Patients. Clin Cancer Res 2016;22:1130-7.

41. Beije N, Sieuwerts AM, Kraan J, et al. Estrogen receptor mutations and splice variants determined in liquid biopsies from metastatic breast cancer patients. Mol Oncol 2018;12:48-57.

42. Murtaza M, Dawson SJ, Pogrebniak K, et al. Multifocal clonal evolution characterized using circulating tumour DNA in a case of metastatic breast cancer. Nat Commun 2015;6:8760.

43. O'Leary B, Hrebien S, Morden JP, et al. Early circulating tumor DNA dynamics and clonal selection with palbociclib and fulvestrant for breast cancer. Nat Commun 2018;9:896.

44. Chung JH, Pavlick D, Hartmaier R, et al. Hybrid capturebased genomic profiling of circulating tumor DNA from patients with estrogen receptor-positive metastatic breast cancer. Ann Oncol 2017;28:2866-73.

45. De Mattos-Arruda L, Weigelt B, Cortes J, et al. Capturing intra-tumor genetic heterogeneity by de novo mutation profiling of circulating cell-free tumor DNA: a proof-ofprinciple. Ann Oncol 2014;25:1729-35.

46. Ma F, Zhu W, Guan Y, et al. ctDNA dynamics: a novel indicator to track resistance in metastatic breast 
cancer treated with anti-HER2 therapy. Oncotarget 2016;7:66020-31.

47. Guttery DS, Page K, Hills A, et al. Noninvasive detection of activating estrogen receptor 1 (ESR1) mutations in estrogen receptor-positive metastatic breast cancer. Clin Chem 2015;61:974-82.

48. Jansen MP, Martens JW, Helmijr JC, et al. Cell-free DNA mutations as biomarkers in breast cancer patients receiving tamoxifen. Oncotarget 2016;7:43412-8.

49. Bidard FC, Pistilli B, Dalenc F, et al. Circulating ESR1 mutation detection rate and early decrease under first line aromatase inhibitor and palbociclib in the PADA-1 trial (UCBG-GINECO) [abstract]. In: Proceedings of the 2018 San Antonio Breast Cancer Symposium; 2018 Dec 4-8; San Antonio, TX. Philadelphia (PA): AACR; Cancer Res 2019;79:Abstract nr PD2-06.

50. Juric D, Ciruelos E, Rubovszky G, et al. Alpelisib + fulvestrant for advanced breast cancer: Subgroup analyses from the phase III SOLAR-1 trial [abstract]. In: Proceedings of the 2018 San Antonio Breast Cancer Symposium; 2018 Dec 4-8; San Antonio, TX. Philadelphia (PA): AACR; Cancer Res 2019;79:Abstract nr GS3-08.

51. Hortobagyi GN, Stemmer S, Campone M, et al. First-line ribociclib + letrozole in hormone receptor-positive, HER2negative advanced breast cancer: Efficacy by baseline circulating tumor DNA alterations in MONALEESA-2 [abstract]. In: Proceedings of the 2017 San Antonio Breast Cancer Symposium; 2017 Dec 5-9; San Antonio, TX. Philadelphia (PA): AACR; Cancer Res 2018;78:Abstract nr PD4-06.

52. Slamon DJ, Neven P, Chia S, et al. Phase III Randomized Study of Ribociclib and Fulvestrant in Hormone ReceptorPositive, Human Epidermal Growth Factor Receptor 2-Negative Advanced Breast Cancer: MONALEESA-3. J Clin Oncol 2018;36:2465-72.

53. Neven P, Petrakova K, Val Bianchi G, et al. Biomarker analysis by baseline circulating tumor DNA alterations in the MONALEESA-3 study [abstract]. In: Proceedings of the 2018 San Antonio Breast Cancer Symposium; 2018 Dec 4-8; San Antonio, TX. Philadelphia (PA): AACR; Cancer Res 2019;79:Abstract nr PD2-05.

54. Baselga J, Im SA, Iwata H, et al. Buparlisib plus fulvestrant versus placebo plus fulvestrant in postmenopausal, hormone receptor-positive, HER2-negative, advanced breast cancer (BELLE-2): a randomised, doubleblind, placebo-controlled, phase 3 trial. Lancet Oncol 2017;18:904-16.

55. Campone M, Im SA, Iwata H, et al. Buparlisib plus fulvestrant versus placebo plus fulvestrant for postmenopausal, hormone receptor-positive, human epidermal growth factor receptor 2-negative, advanced breast cancer: Overall survival results from BELLE-2. Eur J Cancer 2018;103:147-54.

56. Di Leo A, Johnston S, Lee KS, et al. Buparlisib plus fulvestrant in postmenopausal women with hormonereceptor-positive, HER2-negative, advanced breast cancer progressing on or after mTOR inhibition (BELLE-3): a randomised, double-blind, placebo-controlled, phase 3 trial. Lancet Oncol 2018;19:87-100.

57. Takano T, Tsurutani J, Takahashi M, et al. A randomized phase II trial of trastuzumab plus capecitabine versus lapatinib plus capecitabine in patients with HER2positive metastatic breast cancer previously treated with trastuzumab and taxanes: WJOG6110B/ELTOP. Breast 2018;40:67-75.

58. Baird RD, Van Rossum A, Oliveira M, et al. POSEIDON trial phase $1 \mathrm{~b}$ results: Safety and preliminary efficacy of the isoform selective PI3K inhibitor taselisib (GDC-0032) combined with tamoxifen in hormone receptor (HR) positive, HER2-negative metastatic breast cancer (MBC) patients (pts) - including response monitoring by plasma circulating tumor (ct) DNA. J Clin Oncol 2016;34:2520.

59. Ma CX, Bose R, Gao F, et al. Neratinib Efficacy and Circulating Tumor DNA Detection of HER2 Mutations in HER2 Nonamplified Metastatic Breast Cancer. Clin Cancer Res 2017;23:5687-95.

60. Hrebien S, Citi V, Garcia-Murillas I, et al. Early ctDNA dynamics as a surrogate for progression-free survival in advanced breast cancer in the BEECH trial. Ann Oncol 2019;30:945-52.

61. Magbanua MJM, Brown-Swigart L, Hirst GL, et al. Personalized serial circulating tumor DNA (ctDNA) analysis in high-risk early stage breast cancer patients to monitor and predict response to neoadjuvant therapy and outcome in the I-SPY 2 TRIAL [abstract]. In: Proceedings of the 2018 San Antonio Breast Cancer Symposium; 2018 Dec 4-8; San Antonio, TX. Philadelphia (PA): AACR; Cancer Res 2019;79:Abstract nr PD2-01.

62. Sledge GW Jr, Toi M, Neven P, et al. MONARCH 2: Abemaciclib in Combination With Fulvestrant in Women With HR+/HER2- Advanced Breast Cancer Who Had Progressed While Receiving Endocrine Therapy. J Clin Oncol 2017;35:2875-84.

63. Tolaney SM, Toi M, Neven P, et al. Clinical significance of PIK3CA and ESR1 mutations in ctDNA and FFPE samples from the MONARCH 2 study of abemaciclib plus 
fulvestrant [abstract]. In: Proceedings of the American Association for Cancer Research Annual Meeting 2019; 2019 Mar 29-Apr 3; Atlanta, GA. Philadelphia (PA): AACR; Cancer Res 2019; 79:Abstract nr 4458.

64. Kim SB, Dent R, Im SA, et al. Ipatasertib plus paclitaxel versus placebo plus paclitaxel as first-line therapy for metastatic triple-negative breast cancer (LOTUS): a multicentre, randomised, double-blind, placebocontrolled, phase 2 trial. Lancet Oncol 2017;18:1360-72.

65. Wongchenko MJ, Lipson D, Clark T, et al. On-treatment changes in circulating tumor DNA (ctDNA) level as an early predictor of clinical outcome in the LOTUS randomized phase 2 trial of 1st-line ipatasertib (IPAT) + paclitaxel (PAC) for metastatic triple-negative breast cancer (mTNBC) [abstract]. In: Proceedings of the American Association for Cancer Research Annual Meeting 2018; 2018 Apr 14-18; Chicago, IL. Philadelphia (PA): AACR; Cancer Res 2018;78:Abstract nr 2964.

66. Sharma P, Abramson VG, O'Dea A. et al. Clinical and biomarker results from phase I/II study of PI3K inhibitor BYL 719 (alpelisib) plus nab-paclitaxel in HER2-negative metastatic breast cancer. J Clin Oncol 2018;36:1018.

67. Clouthier DL, Lien SC, Yang SYC, et al. An interim report on the investigator-initiated phase 2 study of pembrolizumab immunological response evaluation (INSPIRE). J Immunother Cancer 2019;7:72.

68. James Iafolla MA, Yang C, Dashner S, et al. Bespoke circulating tumor DNA (ctDNA) analysis as a predictive biomarker in solid tumor patients (pts) treated with singleagent pembrolizumab (P). J Clin Oncol 2019;37:2542.

69. Moynahan ME, Chen D, He W, et al. Correlation between PIK3CA mutations in cell-free DNA and everolimus efficacy in HR+, HER2- advanced breast cancer: results from BOLERO-2. Br J Cancer 2017;116:726-30.

70. Ma F, Li Q, Guan X, et al. Safety, efficacy, and biomarker analysis of pyrotinib in combination with capecitabine in HER2-positive metastatic breast cancer patients: a phase I clinical trial [abstract]. J Clin Oncol 2019;37:1035.

71. de Azambuja E, Holmes AP, Piccart-Gebhart M, et al. Lapatinib with trastuzumab for HER2-positive early breast

Cite this article as: Fiste O, Liontos M, Koutsoukos K, Terpos E, Dimopoulos MA, Zagouri F. Circulating tumor DNA-based predictive biomarkers in breast cancer clinical trials: a narrative review. Ann Transl Med 2020;8(23):1603. doi: 10.21037/atm-20-1175 cancer (NeoALTTO): survival outcomes of a randomised, open-label, multicentre, phase 3 trial and their association with pathological complete response. Lancet Oncol 2014;15:1137-46.

72. Rothé F, Silva MJ, Venet D, et al. Circulating Tumor DNA in HER2-Amplified Breast Cancer: A Translational Research Substudy of the NeoALTTO Phase III Trial. Clin Cancer Res 2019;25:3581-8.

73. Tripathy D, Im SA, Colleoni M, et al. Ribociclib plus endocrine therapy for premenopausal women with hormone-receptor-positive, advanced breast cancer (MONALEESA-7): a randomised phase 3 trial. Lancet Oncol 2018;19:904-15.

74. Bardia A, Su F, Solovieff N, et al. Genetic landscape of premenopausal HR+/HER2- advanced breast cancer (ABC) based on comprehensive circulating tumor DNA analysis and association with clinical outcomes in the Phase III MONALEESA-7 trial [abstract]. In: Proceedings of the American Association for Cancer Research Annual Meeting 2019; 2019 Mar 29-Apr 3; Atlanta, GA. Philadelphia (PA): AACR; Cancer Res 2019;79:Abstract nr CT141.

75. Janiaud P, Serghiou S, Ioannidis JPA. New clinical trial designs in the era of precision medicine: An overview of definitions, strengths, weaknesses, and current use in oncology. Cancer Treat Rev 2019;73:20-30.

76. Sellami D, Dharan B, Wilke C, et al. Circulating tumor DNA as a novel tool to shape clinical trial designs with the potential to impact outcomes: a focus on PI3K inhibitors. Ann Oncol 2017;28:2882-7.

77. Cardoso F, Kyriakides S, Ohno S, et al. Early breast cancer: ESMO Clinical Practice Guidelines for diagnosis, treatment and follow-up. Ann Oncol 2019;30:1674.

78. Available online: www.fda.gov/medical-devices/vitrodiagnostics/list-cleared-or-approved-companiondiagnostic-devices-vitro-and-imaging-tools

79. The Blood Profiling Atlas in Cancer (BloodPAC) Consortium. Available online: https://www.bloodpac.org/

80. Cancer - ID Consortium. Available online: https://www. cancer-id.eu/ 